\section{AIDS dissidents aren't victims - but the people their ideas kill will be}

Sir - As South African scientists working in the field of HIV/AIDS vaccine research, we are extremely concerned about the letter president Thabo Mbeki recently sent other heads of state (Nature 404, 911; 2000). As an individual Mr Mbeki is entitled to his point of view, but as our head of state we feel he risks binding our country to an untenable position.

Mr Mbeki's comments that distress us most are these:

\section{1: "It is suggested ... that there are some} scientists who are 'dangerous and discredited' with whom nobody ... should communicate or interact ... We are now being asked to do precisely the same thing that the racist apartheid tyranny we opposed did, because, it is said, there exists a scientific view that is supported by the majority, against which dissent is prohibited."

This is unfair. The views of the 'AIDS dissidents', publicly aired when the debate was current, are largely ignored now because most experts do not believe they have any currency in the light of today's knowledge. Yet the 33-member committee Mr Mbeki has convened to advise his government contains as many 'AIDS dissidents' from other countries as South African scientists. Less than half of the total are HIV/AIDS experts (see Nature 405, 105; 2000).

\section{2: "The scientists we are supposed to put} into scientific quarantine include Nobel prizewinners, members of academies of science and emeritus professors of various disciplines of medicine!"

This is a misleading statement: distinguished though these people may be, if they have not worked in areas concerning HIV/AIDS they may not be well-enough informed to have credibility in this debate.

3: "People who otherwise would fight very hard to defend the critically important rights of freedom of thought and speech occupy, with regard to the HIV/AIDS issue, the frontline in the campaign of intellectual intimidation and terrorism which argues that the only freedom we have is to agree with what they decree to be established scientific truths."

This is incorrect. 'AIDS dissidents' promote the idea that unholy alliances of pharmaceutical companies and funding bodies are bent on silencing them. The fact is that, if one's scientific views are very obviously not being backed up by other people's findings, one's scientific credibility is lessened.

Internationally, science is a democratic institution: as such we would hope that $\mathrm{Mr}$ Mbeki would sympathize with it. This case has clear historical parallels with the championing of Trofim Lysenko's flawed science by the authorities in the former Soviet Union, and with the 'scientific' justifications of apartheid by the old South Africa. Neither is a good example to follow!

4: "It may be that these comments are extravagant. If they are, it is because in the very recent past, we had to fix our own eyes on the very face of tyranny."

This is irrelevant to the country's AIDSrelated crisis. The previous government was guilty of inaction in the face of a threatened epidemic; the present government has not done enough in the past five years to stave off the disaster that now threatens us.

We would like Mr Mbeki and others to consider how the mass of South Africans would react if he were to give a sympathetic ear to unrepentant proponents of apartheid. His willingness to be influenced by people with no credibility causes as much anguish to those of us working to combat HIV/AIDS.

The simple facts, as shown by a huge volume of scientific and medical research, are that HIV causes AIDS; that in Africa (as in other developing regions) the disease is mainly spread heterosexually; and that AIDS kills poor people in disproportionate numbers. We most emphatically do not need to revisit the debate on the causation of AIDS. What we do urgently need is to educate, train and medicate, to save lives.

As long as Mr Mbeki is being advised by people with no credibility, we as South African scientists feel dangerously marginalized in the search for solutions to HIV/AIDS. Edward Rybicki ${ }^{\star}$, Anna-Lise Williamson $\dagger$, Lynn Morris $\ddagger$

${ }^{*}$ Department of Microbiology, University of Cape Town, PB Rondebosch 7701, South Africa $\dagger$ Department of Medical Microbiology, University of Cape Town, PO Observatory 7925, South Africa $\$$ National Institute for Virology, Private Bag X4, Sandringham, Johannesburg 2131, South Africa The authors are members of a consortium sponsored by the South African AIDS Vaccine Initiative, seeking to formulate vaccines to the HIV-1 subtype C viruses prevalent in the area.

\section{Bureaucracy strangles Latin American research}

Sir - In his special supplement on science in Latin America last year, Colin Macilwain ${ }^{1}$ rightly pointed out that scientists in most countries in the region complain about excessive bureaucracy and the time wasted by customs authorities in processing scientific equipment and materials for research.
But the major problem is in the enormous, inefficient bureaucratic system that reigns in almost all Latin American government institutions, not just in universities.

The system does not serve academic researchers: it creates all types of administrative bottlenecks. Most universities employ more administrative staff than teaching staff, using up a major part of the budget in unnecessary paperwork as well as for their salaries and bonuses.

The general administration of a university maintains four or five divisions with titles such as "purchasing", "budget", "finance", "control" and so on, each section maintaining large numbers of staff, each with a specific role. If one person does not function, the rest stand still. The simplest transaction, for example payment of expenses to attend a scientific meeting, will probably not be completed until the event is over, unless the researcher personally tracks the file from desk to desk. Every four years, the authorities change and the new ones introduce their own systems, allegedly for efficiency but in fact to justify hiring new people. So a new bottleneck is created. This growth of administration can come only at the expense of research and teaching ${ }^{2}$.

The causes of administrative growth in Latin American universities are complex. This growth probably stems partly from Cordoba's university reform ${ }^{3}$ in 1918 , and partly from earlier movements for the democratization of the Latin American universities in Uruguay, where the idea of an autonomous democratic university first emerged. Cordoba's reform movement was an important influence in replacing the autocracy of Latin American universities with a democratic campus system. But later developments - including an excess of politics and the development of trades unions among the administrative staff and students - have eroded the original initiative in many universities.

Drastic measures are required to minimize bureaucracy and improve efficiency, but university authorities (which are elected) will not risk their popularity. A few countries in the region have had some success in cutting their administrations down to size, but this has not been possible in others because of powerful unions and rigid control by the administrative system.

University managements have a responsibility to create a more dynamic, efficient research environment. Governments in the region should hold them responsible for unproductiveness in research and teaching. Julio E. Pérez, Abul K. Bashirullah Instituto Oceanográfico, Universidad de Oriente, Apartado Postal 138, Cumana 6101, Venezuela 1. Macilwain, C. Nature 398 supp., A10 (1999).

2. Finn, R. The Scientist 11, 13 (1997).

3. Peñalver, L. M. Teoría y Praxis de la Universidad a Distancia. (Fondo Editorial para el Desarrollo del Educación Superior, Caracas, 1992). 